\title{
Assemblage and diversity of asexual fungi in 10 terrestrial damp leaf litters: Comparison of two incubation techniques
}

\author{
Sridhar $\mathbf{K R}^{1,2}$, Nagesh $\mathbf{H}^{1}$, Sharathchandra $\mathrm{K}^{1}$ \\ ${ }^{1}$ Department of Biosciences, Mangalore University, Mangalagangotri, Mangalore, Karnataka, India \\ ${ }^{2}$ Centre for Environmental Studies, Yenepoya (deemed to be) University, Mangalore, Karnataka, India
}

Sridhar KR, Nagesh H, Sharathchandra K 2020 - Assemblage and diversity of asexual fungi in 10 terrestrial damp leaf litters: Comparison of two incubation techniques. Asian Journal of Mycology 3(1), 362-375, Doi 10.5943/ajom/3/1/10

\begin{abstract}
Freshwater and aero-aquatic hyphomycetes are also known to occur outside their usual aquatic habitats. Thus, this study aims to evaluate their assemblage and diversity in terrestrial damp leaf litters of 10 tree species in scrub jungles of southwestern India. Discs cut from the rinsed leaf litter collected during southwest monsoon were incubated in damp chambers ( 2 weeks) and bubble chambers (48 hours). Post-incubation at the damp chamber, discs were transferred to sterile, distilled water and shaken on a rotary shaker to release the conidia. Another set of leaf discs from rinsed leaf litter was incubated in sterile distilled water in cotton plugged conical flasks and bubbled through Pasteur pipettes. Released conidia in distilled water were filtered through Millipore filters, mounted on the microscope slides and stained with aniline blue to score the conidia. A total of 31 species of aquatic hyphomycetes were recorded in both methods of incubation. Even though the total number of species ( $21 \mathrm{vs} 20 \mathrm{spp}$.) and exclusive species (11 vs 10 spp.) were almost equal in both methods, the species composition is varied. Among the nine coregroups (frequency of occurrence, >25\%), Flagellospora curvula, Lunulospora curvula and Triscelophous konajensis were common in both methods. The species richness, as well as the conidial abundance were higher for Acacia auriculiformis, Ficus benghalensis and Tectona grandis in litters using both methods. For Artocarpus hirsutus, Careya arborea and Terminalia paniculata, the species richness was high but the conidial output was very low. Despite showing a higher number of species for Artocarpus hirsutus, Eucalyptus tereticornis and Ficus religiosa using both methods, the conidial richness was high only in damp incubation, while it was opposite for the Anacardium occidentale. The species diversity, as well as their equitability, were higher in the damp chamber than bubble chamber incubation. The rarefaction curves for the number of species vs. number of samples and the number of species vs. number of conidia were almost consistent in both methods. Damp chamber incubation, as well as bubble chamber incubation, could be improved to get a more complete picture of colonized mycota in damp leaf litter.
\end{abstract}

Key words - aquatic fungi - aero-aquatic fungi - bubble chamber - damp chamber - Ingoldian fungi - scrub jungles

\section{Introduction}

Freshwater fungi consist of phylogenetically diverse groups of fungi belonging to Ascomycota, Chytridiomycota, Cryptomycota and Zygomycota in different habitats (Hyde \& 
Jeewon 2003, Vijaykrishna et al. 2005, Raja et al. 2018, Luo et al. 2019). The lifestyle of freshwater fungi widely differs (e.g. saprophytic, planktonic, endophytic, pathogenic and parasitic) and dependent on the specificity of their ecological niches (Zhang et al. 2008, Huang et al. 2018a, b). Ascomycetes are well adapted to freshwater habitats (Vijaykrishna et al. 2006). The diversity of freshwater fungi is rather high in the South East Asian region with many new species discovered recently (Luo et al. 2017, Bao et al. 2018, Su et al. 2018). Freshwater hyphomycetes (or Ingoldian fungi) have been characterized by their morphologically distinct staurosporus (multiradiate) and scolecosporus (sigmoid) conidia (Ingold 1975, Marvanová 1997, Gulis et al. 2005). However, some of them produce conidia of conventional shapes like spherical or oval or fusiform (e.g. Dimorphospora, Tumularia and Vermispora). The complexity of conidial shapes denotes functional traits in aquatic habitats especially floatation, impaction, sedimentation and dissemination.

Aquatic hyphomycetes have a worldwide distribution, and 335 morphospecies have been reported with preponderance in freshwaters of mid-latitudes (Duarte et al. 2016, Friggens et al. 2017). Although aquatic hyphomycetes have adapted to flowing waters, they also occur outside their preferred habitats, especially in several tree species or its detritus throughout the world (Chauvet et al. 2016). Colonization and sporulation of aquatic and aero-aquatic hyphomycetes have been reported from habitats such as stream banks, dew, canopy waters and tree holes (Sridhar \& Kaveriappa 1987, Sridhar 2009, Sridhar \& Bärlocher 1993). Typical aquatic and aero-aquatic hyphomycetes have been reported from the forest floors, forest canopies (tree holes, stemflow and throughfall) and as endophytes from the aerial plant parts (Chauvet et al. 2016). Aero-aquatic hyphomycetes are predominant in lotic habitats. They build their biomass in submerged conditions and produce conidia in the air-water interface. They are also the inhabitants of semi-aquatic habitats and moist forest litters (leaf, twigs and wood). Helicoma, Helicoön, Helicosporium, Helicomyces and Spirosphaera are characterized by two or three-dimensionally coiled spores as a special adaption for flotation (Zhao et al. 2007, Luo et al. 2017). From the aquatic habitats, up to 90 aero-aquatic hyphomycete species (in 19 genera) have been reported worldwide (Shearer et al. 2007, Raja et al. 2018). Hence, the purpose of the present study is to assess the assemblage and diversity of aquatic and aero-aquatic hyphomycetes in the damp leaf litter of 10 tree species in the scrub jungles of southwestern India during southwest monsoon season.

\section{Materials \& Methods}

\section{Location and sample collection}

The geographic location chosen for the microfungal survey was Mangalore University Campus located $\sim 5 \mathrm{~km}$ away from the Arabian Sea coast adjacent to the Mangalore City (Dakshina Kannada District, Karnataka State) $\left(12^{\circ} 48^{\prime} \mathrm{N}, 74^{\circ} 55^{\prime} \mathrm{E}\right.$; $104-112 \mathrm{~m}$ asl). The vegetation in this undulating terrain $(\sim 150 \mathrm{ha})$ was initially grassland and developed patches of scrub jungles for the last five decades. The natural scrub vegetation builds up gradually and the plantation of cashew (Anacardium occidentale) was established in the early 1970s. Subsequently, the forest department has developed mixed plantations (e.g. Acacia, Anacardium, Azadirachta, Casuarina, Cocos and Pongamia). Several native tree species build up subsequently with minimum human interference (e.g. Borassus, Careya, Caryota, Holigarna, Hopea, Macaranga, Sapium, Syzygium, Tamarindus and Terminalia).

The survey of asexual fungi associated with damp leaf litters of 10 tree species was carried out in the southwest monsoon period (July 08-15, 2019). Schematic presentation of the study carried out has been given in Figure 1. The tree species selected in scrub jungles for leaf litter collection were Acacia auriculiformis, Anacardium occidentale, Artocarpus heterophyllus, Artocarpus hirsutus, Careya arborea, Eucalyptus tereticornis, Ficus benghalensis, Ficus religiosa, Tectona grandis and Terminalia paniculata. Humidity (beneath the canopy), air temperature (in shade below the canopy) (Mextech Digital Thermo Hygrometer M288CTHW, Mextech Technologies India Private Limited, Mumbai, Maharashtra, India) and soil temperature (mercury thermometer) below the canopy $(8-10 \mathrm{~cm}$ depth) were measured during each day of sampling. The 
damp leaf litter underneath the trees were collected (from three replicate trees) (Fig. 2) and rinsed in tap water followed by distilled water to remove the debris. They were cut into $1.2 \mathrm{~cm}$ disks using a cork borer. The leaf discs were again rinsed in distilled water followed by incubation.

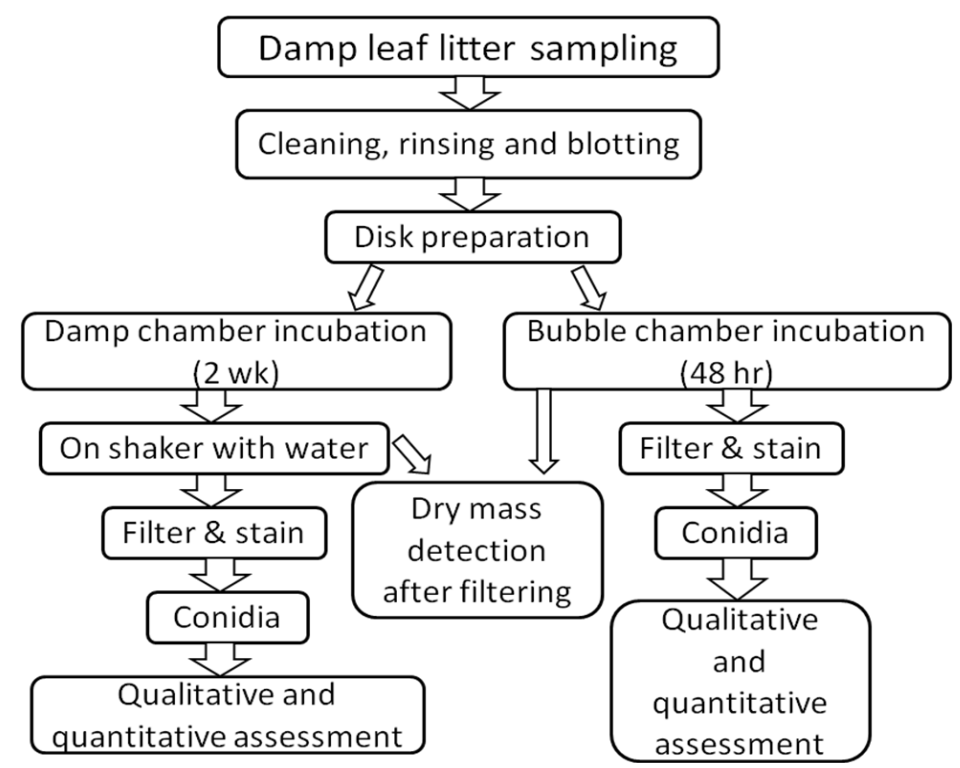

Fig. 1 - The schematic presentation of methodology followed to study aquatic hyphomycetes in terrestrial damp leaf litters.
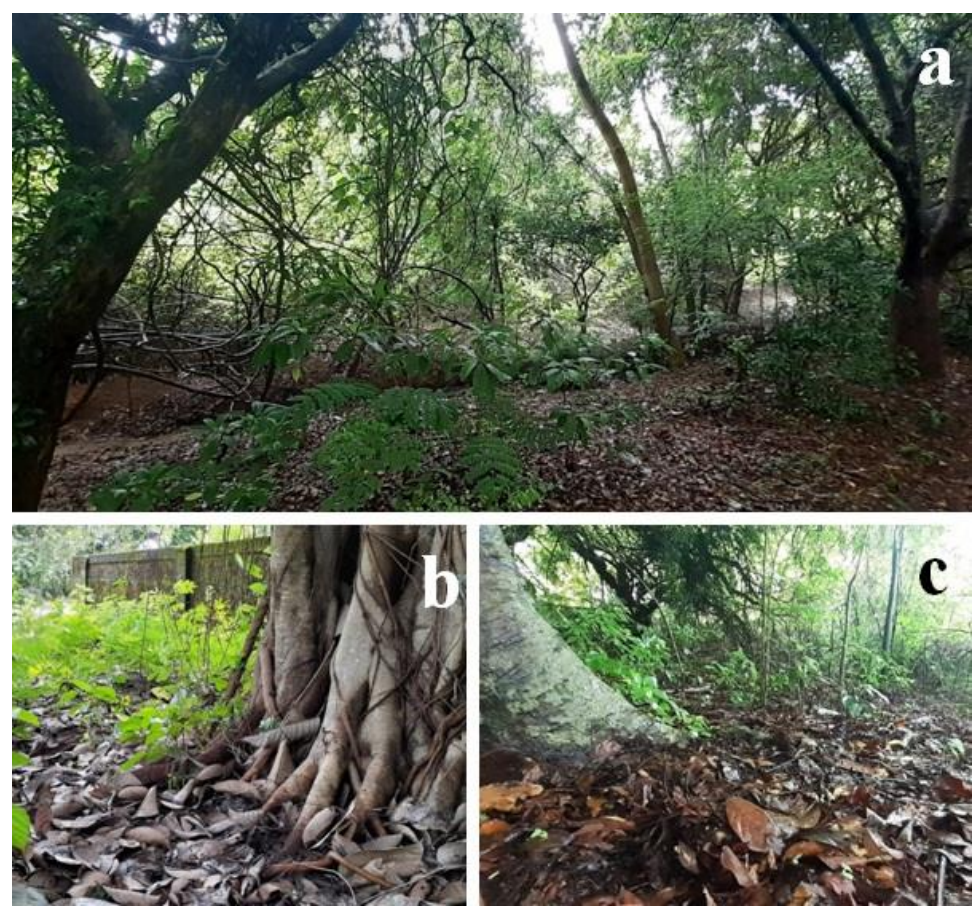

Fig. 2 - Sample collection sites. a View of a scrub jungle of southwestern India. b Accumulation of leaf litter in the basin of banyan (Ficus benghalensis). c Wild jack (Artocarpus hirsutus).

\section{Damp chamber incubation}

Four leaf discs from four individual leaf litter samples of each tree species served as one replicate. Those leaf discs were placed on a folded paper towel in $10 \mathrm{~cm}$ Petri dishes. A small quantity of sterile distilled water was added to wet the paper towel periodically. This allows the leaf discs to receive water similar to the natural habitat (without submersion). Likewise, three replicate plates were prepared per tree species and incubated at room temperature $\left(25 \pm 3^{\circ} \mathrm{C}\right)$ up to two weeks. 
After two weeks, four leaf-discs in each Petri plate were transferred to conical flasks $(100 \mathrm{ml}$ capacity) containing $25 \mathrm{ml}$ sterile distilled water and shaken for about $15 \mathrm{~min}$ at $100 \mathrm{rpm}$ to release the conidia of fungi developed on the leaf discs. Water in flasks was filtered through Millipore filters $(5 \mu \mathrm{m} ; 3 \mathrm{~cm}$ diam.). The filters were stained with few drops of aniline blue in lactophenol and preserved in the dark until observation. Each disc was mounted on a microscope slide by addition of a few drops of lactic acid and examined to measure the conidia of hyphomycetes using low-power and high-power microscope (Nikon YS100, Nikon Corporation, Tokyo, Japan). Identification was carried out based on monographs and individual papers (Ingold 1975, Nawawi 1985, Marvanová 1997, Santos-flores \& Betancourt-Lopez 1997, Gulis et al. 2005, Zhao et al. 2007). The dry mass of leaf discs in each Petri plate was determined gravimetrically by drying at $80^{\circ} \mathrm{C}$ for $24 \mathrm{hr}$ in a hot-air oven.

\section{Bubble chamber incubation}

The leaf discs prepared as described above in damp chamber incubation were transferred to conical flasks $(250 \mathrm{ml})$ containing $150 \mathrm{ml}$ sterile distilled water. The discs were aerated using aquarium aerators through Pasteur pipettes up to 48 hours to allow the mycelia present in the leaf discs to develop and release the conidia. After aeration, the aerated water was filtered through Millipore filters $(5 \mu \mathrm{m} ; 4.7 \mathrm{~cm}$ diam.), stained with aniline blue and screened for the presence of conidia. The dry mass of leaf discs in each flask was determined gravimetrically by drying at $80^{\circ} \mathrm{C}$ for $24 \mathrm{hr}$ in a hot-air oven.

\section{Data analysis}

The frequency of occurrence (FO) of each species in the damp chamber and bubble chamber incubations were calculated as follows:

$$
\text { FO }(\%)=\left(\frac{T_{s}}{T_{a}}\right) \times 100
$$

(where Ts, Total number of samples that possess a specific species; Ta, Total number of samples assessed).

The relative abundance (RA) of each species in the damp chamber and bubble chamber incubations was calculated as follows:

$$
\mathrm{RA}(\%)=\left(\frac{F_{5}}{F_{a}}\right) \times 100
$$

(where Fs, Frequency of occurrence of each species; Fa, Sum of frequency of occurrence of all species).

The Simpson's diversity $\left(D^{\prime}\right)$, Shannon's diversity $\left(H^{\prime}\right)$ (Magurran 1988) and Pielou's equitability $\left(J^{\prime}\right)$ (Pielou 1975) indices for aquatic hyphomycetes on leaf discs, on the damp chamber and bubble chamber incubations were calculated as given below:

$$
\begin{aligned}
& D^{\prime}=\left(\frac{1}{\Sigma(p i) 2}\right) \times 100 \\
& H^{s}=-\Sigma(p i \ln p i)
\end{aligned}
$$

(where, $p_{i}$ is the proportion of individual that species $i$ contributes to the total).

$$
l^{p}=\left(\frac{H^{v}}{H^{\top} \max }\right)
$$


(where, $H_{\text {max }}^{\prime}$ is the maximum value of diversity for the number of species present).

To compare the richness of fungal species among the incubation techniques, rarefaction indices were calculated (Ludwig \& Reynolds 1988). The expected number of fungal species $\left[E_{(s)}\right]$ in a random of $n$ samples taken from a total $N$ samples was estimated:

$$
E(s)=\sum_{i=1}^{s}\left\{1-\left[\left(\begin{array}{c}
N-n_{\tilde{i}} \\
n
\end{array}\right) /\left(\begin{array}{l}
N \\
n
\end{array}\right)\right]\right\}
$$

(where, $n_{i}$ is the occurrence of $i$ th species in number of samples).

Similarly, the expected number of fungal species $\left[E_{(s)}\right]$ in a random sample of $n$ conidia from a total of $N$ conidia was estimated (where, $n_{i}$ is the number of conidia of $i$ th species in a total number of conidia scored).

\section{Results}

\section{Temperature and humidity}

July is the peak period of rainfall during the southwest monsoon in southwest India. During the survey period in July, the soil temperature ranged from $25.3^{\circ} \mathrm{C}$ (Artocarpus hirsutus) to $28^{\circ} \mathrm{C}$ (Acacia auriculiformis and Ficus benghalensis) (Table 1). Air temperature ranged from $24.7^{\circ} \mathrm{C}(\mathrm{A}$. hirsutus and Careya arborea) to $30.7^{\circ} \mathrm{C}$ (Eucalyptus tereticornis). Humidity ranged from $66 \%$ (Eucalyptus tereticornis) to $88.7 \%$ (A. hirsutus). On $15^{\text {th }}$ of July 2019 , the least soil temperature, least air temperature and the highest humidity were reported beneath the trees of A. hirsutus. Similarly, the highest air temperature $\left(30.7^{\circ} \mathrm{C}\right)$ and least humidity $(66 \%)$ was seen beneath the canopy of E. tereticornis. The mean soil temperature, air temperature and relative humidity were $26.9^{\circ} \mathrm{C}, 27.3^{\circ} \mathrm{C}$ and $77.5 \%$, respectively.

Table 1 Temperature and humidity during leaf litter sampling in the scrub jungles ( $n=3$, mean).

\begin{tabular}{lccccc}
\hline & Code & Sampling date & \multicolumn{2}{c}{$\begin{array}{c}\text { Temperature } \\
\left({ }^{\circ} \mathbf{C}\right)\end{array}$} & $\begin{array}{c}\text { Humidity } \\
(\mathbf{\%})\end{array}$ \\
\cline { 3 - 6 } & & & Soil & Air & \\
\hline Acacia auriculiformis A. Cunn. ex & ACAU & July 08, 2019 & 28.0 & 29.7 & 72.3 \\
Benth. & & & & \\
Anacardium occidentale L. & ANOC & July 04, 2019 & 27.8 & 26.7 & 85.7 \\
Artocarpus heterophyllus Lam. & ARHE & July 10, 2019 & 26.0 & 26.3 & 79.0 \\
Artocarpus hirsutus Lam. & ARHI & July 15, 2019 & 25.3 & 24.7 & 88.7 \\
Careya arborea Roxb. & CAAR & July 15, 2019 & 26.0 & 24.7 & 83.7 \\
Eucalyptus tereticornis Sm. & EUTE & July 13, 2019 & 27.2 & 30.7 & 66.0 \\
Ficus benghalensis L. & FIBE & July 04, 2019 & 28.0 & 27.1 & 80.7 \\
Ficus religiosa L. & FIRE & July 13, 2019 & 27.7 & 28.3 & 69.3 \\
Tectona grandis L.f. & TEGR & July 10, 2019 & 26.0 & 26.0 & 78.0 \\
Terminalia paniculata Roth & TEPA & July 08, 2019 & 27.3 & 29.1 & 71.7 \\
\hline Average & & & 26.9 & 27.3 & 77.5 \\
\hline Range & & July 04- & $25.3-$ & $24.7-$ & $66-$ \\
& & 15,2019 & 28 & 30.7 & 88.7 \\
\hline
\end{tabular}

\section{Damp chamber incubation}

Damp chamber incubation resulted in the occurrence of 21 species of hyphomycetes (Table 2, Figs 3, 4). Flagellospora curvula showed the highest frequency of occurrence $(52.8 \%)$ and Dwayaangam sp. and triradiate conidial fungus showed the least $(6.6 \%$ each). Nine species 
belonged to core- group with the frequency of occurrence above $25 \%$ (26.4-52.8\%). The leaf discs of $F$. benghalensis showed the highest mean number of hyphomycetes $(8 \mathrm{spp}$.) followed by leaf discs of E. tereticornis (6 spp.) and A. heterophyllus (5.7 spp.), while the leaf discs of T. paniculata showed the least (4 spp.) (Fig. 5a). The mean conidial output was the highest in $F$. religiosa and $T$. grandis (857 conidia/g) followed by A. auriculiformis (803 conidia/g), E. tereticornis (620 conidia/g) and $F$. benghalensis (610 conidia/g), while it was least in A. occidentale (143 conidia/g) (Fig. 5b). The observed species richness in damp incubation was 21 species, while the expected number of species $\left[E_{(s 110)}\right]$ based on rarefaction was 30 species at 110 random samples (Table 3, Fig. 6a). Simpson's and Shannon's diversities were 0.942 and 4.232, respectively, and the Pielou's equitability was 0.963 . The expected number of species $\left[E_{(s 500)}\right]$ attained the highest $(30 \mathrm{spp}$.) at 500 random counts of conidia (Fig. 7a).

Table 2 Frequency of occurrence (FO) and relative abundance (RA) of aquatic hyphomycetes in leaf litter by damp chamber incubation $\left(^{*}\right.$, Exclusive species; **, Occurred also in bubble chamber incubation)

\begin{tabular}{lcc}
\hline & FO (\%) & RA (\%) \\
\hline **Flagellospora curvula Ingold (Fig. 3d) & 52.8 & 10.0 \\
*Tumularia aquatica (Ingold) Descals \& Marvanová (Fig. 4h) & 46.2 & 8.8 \\
**Lunulospora curvula Ingold (Fig. 3j) & 42.9 & 8.2 \\
**Lateriramulosa uni-inflata Matsush. (Fig. 3i) & 36.3 & 6.9 \\
*Speiropsis pedatospora Tubaki (Fig. 4a) & 29.7 & 5.6 \\
**Wiesneriomyces laurinus (Tassi) P.M. Kirk (Fig. 4i) & 29.7 & 5.6 \\
*Anguillospora crassa Ingold & 26.4 & 5.0 \\
*Helicosporium sp. 1 (Fig. 3e) & 26.4 & 5.0 \\
**Triscelophorus konajensis K.R. Sridhar \& Kaver. (Fig. 4f) & 26.4 & 5.0 \\
*Helicosporium sp. 2 (Fig. 3f) & 23.1 & 4.4 \\
*Helicosporium sp. 3 & 23.1 & 4.4 \\
*Tripospermum camelopardus Ingold, Dann \& P.J. McDougall & 23.1 & 4.4 \\
(Fig. 4b) & 23.1 & 4.4 \\
**Triscelophorus monosporus Ingold (Fig. 4g) & 19.8 & 3.8 \\
**Phalangispora constricta Nawawi \& J. Webster (Fig. 3k) & 19.8 & 3.8 \\
**Triscelophorus acuminatus Nawawi (Fig. 4e) & 16.5 & 3.1 \\
**Anguillospora longissima (Sacc. \& P. Syd.) Ingold & 16.5 & 3.1 \\
**Flabellospora verticillata Alas. (Fig. 3c) & 13.2 & 2.5 \\
*Flagellospora penicillioides Ingold & 13.2 & 2.5 \\
*Anguillospora angulata (R.H. Petersen) Wolfe & 6.6 & 1.3 \\
*Dwayaangam sp. (Fig. 3b) & 6.6 & 1.3 \\
*Unknown (triradiate conidia) (Fig. 4d) & & \\
\hline
\end{tabular}

\section{Bubble chamber incubation}

The bubble chamber incubation of leaf discs resulted in the occurrence of 20 species of aquatic hyphomycetes (Table 4, Figs 3, 4). Triscelophorus acuminatus showed the highest frequency of occurrence (83.3\%) and Lateriramulosa uni-inflata and Tripospermum myrti showed the least $(3.3 \%$ each). Nine species were core-group species with the frequency of occurrence above $25 \%$ (26.7-83.3\%). The leaf discs of $A$. hirsutus showed the highest mean number of aquatic hyphomycetes (8.3 spp.) followed by $F$. benghalensis (8 spp.), C. arborea (7.3 spp.) and A. auriculiformis (7 spp.), while it was least in F. religiosa (4 spp.) (Fig. 5a). The mean conidial output was highest in the discs of $F$. benghalensis ( 987 conidia/g) followed by A. occidentale (627 conidia/g) and T. grandis (543 conidia/g), while it was least in A. heterophyllus (107 conidia/g) 
(Fig. 5b). The observed species richness in damp incubation was 20 species, while the expected number of species $\left[E_{(s 110)}\right]$ based on rarefaction was 30 species at 110 random samples (Table 2, Fig. 6b). The Simpson's and Shannon's diversities were 0.672 and 2.686, respectively, and the Pielou's equitability was 0.622 . The expected number of conidia species attained maximum at 110 samples (30 spp.) and saturated at 180 samples. The expected number of species $\left[E_{(s 500)}\right]$ attained the highest (30 spp.) at 500 random counts of conidia (Fig. 7b).

Table 3 Species richness, diversity and evenness of aquatic hyphomycetes in two methods of incubation

\begin{tabular}{lcc}
\hline & Damp chamber incubation & Bubble chamber incubation \\
\hline $\begin{array}{l}\text { Observed species richness among } 30 \\
\text { samples }\end{array}$ & 21 & 20 \\
$\begin{array}{l}\text { Expected number of species in samples } \\
{\left[E s_{(s 110)}\right]}\end{array}$ & 30 & 30 \\
Expected number of species in conidia & 30 & 30 \\
{$\left[E s_{(s 50)}\right]$} & & \\
Simpson's diversity & 0.942 & 0.672 \\
Shannon's diversity & 4.232 & 2.686 \\
Pielou's equitability & 0.963 & 0.622 \\
\hline
\end{tabular}

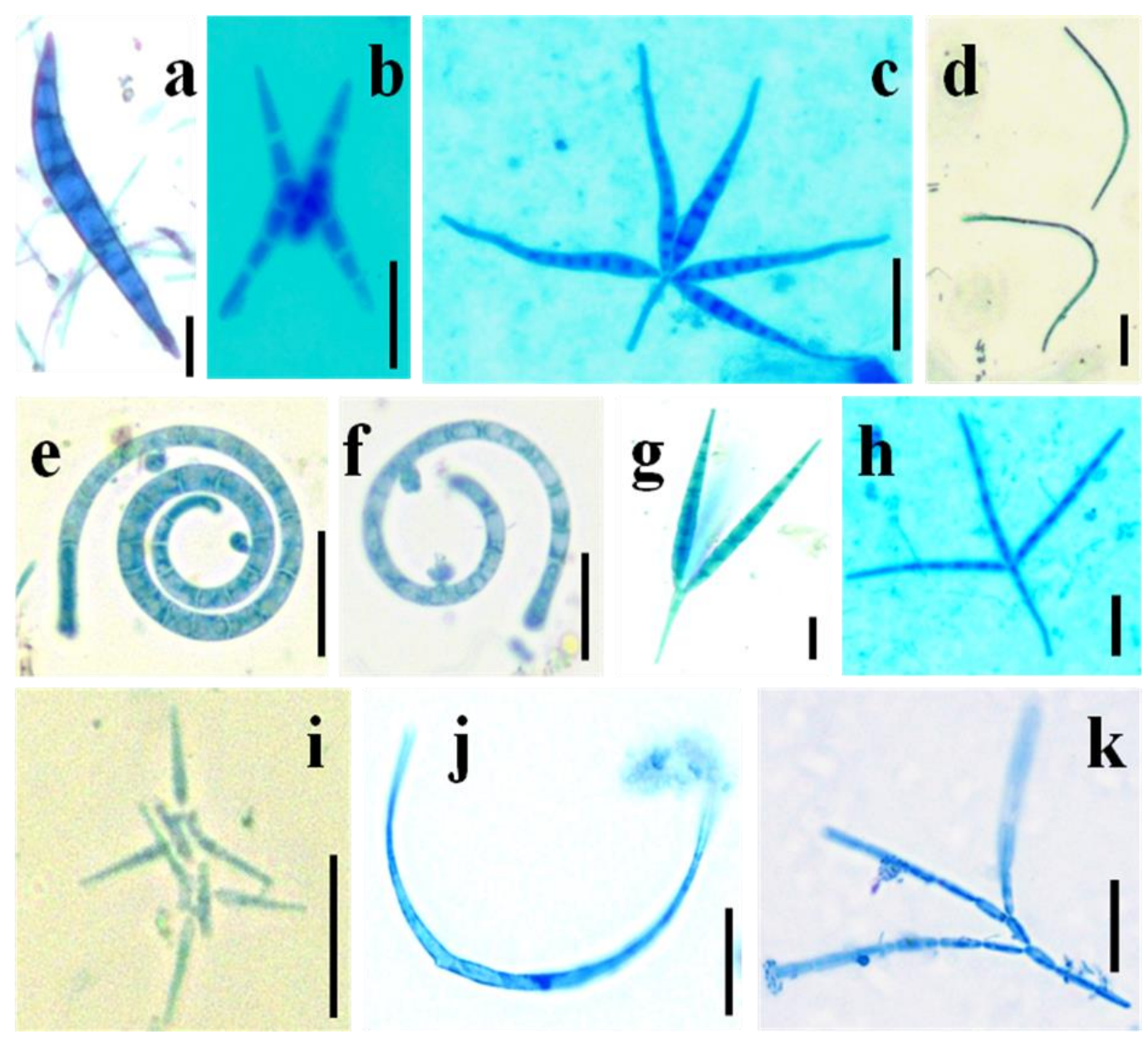

Fig. 3 - Conidia. a Anguillospora sp. b Dwayaangam sp. c Flabellospora verticillata. d Flagellospora curvula. e Helicosporium sp. 1. f Helicosporium sp. 2. g Isthmotricladia gombakiensis. h Isthmotricladia laeensis. i Lateriramulosa uni-inflata. j Lunulospora curvula. $\mathrm{k}$ Phalangispora constricta. Scale bar: $20 \mu \mathrm{m}$. 


\section{Comparison of incubation methods}

A total of 31 species of aquatic hyphomycetes were recorded using two incubation methods (Tables 3, 4). The total number of species ( $21 \mathrm{vs} 20 \mathrm{spp}$.) and the exclusive species (11 vs $10 \mathrm{spp}$.) were almost similar in both methods of incubation. However, species composition and the conidial output differs among the methods of incubation (Figs 5a, b). The species and conidial richness were high in leaf litters of $A$. auriculiformis, $F$. benghalensis and T. grandis in both methods. Even though the species richness was higher in leaf litters of A. hirsutus, C. arborea and T. paniculata was higher in both methods, the conidial output was very low. In spite of high species richness in both methods of incubation of leaf litters of A. hirsutus, E. tereticornis and F. religiosa, the conidial richness was higher only in damp incubation, while it was opposite for the A. occidentale.

The observed species richness was almost the same in both incubation methods (20-21 spp.). The Simpson's diversity, Shannon's diversity and Pielou's equitability were higher in damp chamber incubation than bubble chamber incubation (Table 2). The rarefaction curves for species richness based on the samples as well as conidia were almost similar in both methods (Figs 6, 7).

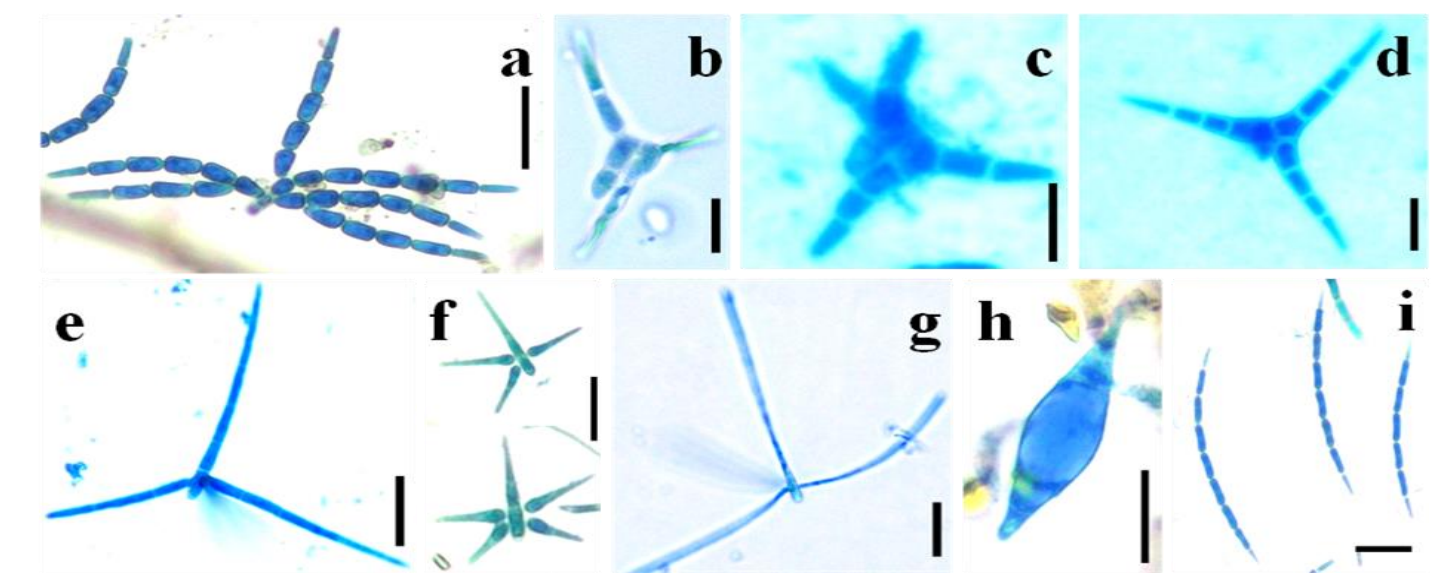

Fig. 4 - Conidia of: a Speiropsis pedatospora. b Tripospermum camelopardus. c Tripospermum myrti. d unknown triradiate conidia. e Triscelophorus acuminatus. f Triscelophorus konajensis. $\mathrm{g}$ Triscelophorus monosporus. h Tumularia aquatica. i Wiesneriomyces laurinus. Scale bar: $20 \mu \mathrm{m}$.

Table 4 Frequency of occurrence (FO) and relative abundance (RA) of aquatic hyphomycetes in leaf litter by bubble chamber incubation (* Exclusive species; ** Occurred also in damp chamber incubation)

\begin{tabular}{lcc}
\hline & FO (\%) & RA (\%) \\
\hline **Triscelophorus acuminatus Nawawi (Fig. 4e) & 83.3 & 14.0 \\
**Triscelophorus konajensis K.R. Sridhar \& Kaver. (Fig. 4f) & 76.7 & 12.9 \\
**Flagellospora curvula Ingold (Fig. 3d) & 70.0 & 11.7 \\
**Triscelophorus monosporus Ingold (Fig. 4g) & 60.0 & 10.1 \\
**Lunulospora curvula Ingold (Fig. 3j) & 46.7 & 7.8 \\
*Unknown (sigmoid conidia) & 40.0 & 6.7 \\
**Phalangispora contricta Nawawi \& J. Webster (Fig. 3k) & 30.0 & 5.0 \\
**Flabellospora verticillata Alas. (Fig. 3c) & 30.0 & 5.0 \\
*Isthmotricladia laeensis Matsush. (Fig. 3h) & 26.7 & 4.5 \\
*Tricladium sp. & 20.0 & 3.4 \\
*Alatospora acuminata Ingold & 16.7 & 2.8 \\
*Ingoldiella hamata D.E. Shaw & 16.7 & 2.8 \\
*Anguillospora sp. (Fig. 3a) & 16.7 & 2.8 \\
**Wiesneriomyces laurinus (Tassi) P.M. Kirk (Fig. 4i) & 16.7 & 2.8 \\
\hline
\end{tabular}


Table 4 Continued.

\begin{tabular}{lcc}
\hline & FO (\%) & RA (\%) \\
\hline *Isthmotricladia gombakiensis Nawawi (Fig. 3g) & 13.3 & 2.2 \\
**Anguillospora longissima (Sacc. \& P. Syd.) Ingold & 10.0 & 1.7 \\
*Campylospora chaetocladia Ranzoni & 10.0 & 1.7 \\
*Campylospora parvula Kuzuha & 6.7 & 1.1 \\
**Lateriramulosa uni-inflata Matsush. (Fig. 3i) & 3.3 & 0.6 \\
*Tripospermum myrti (Lind) S. Hughes (Fig. 4c) & 3.3 & 0.6 \\
\hline
\end{tabular}

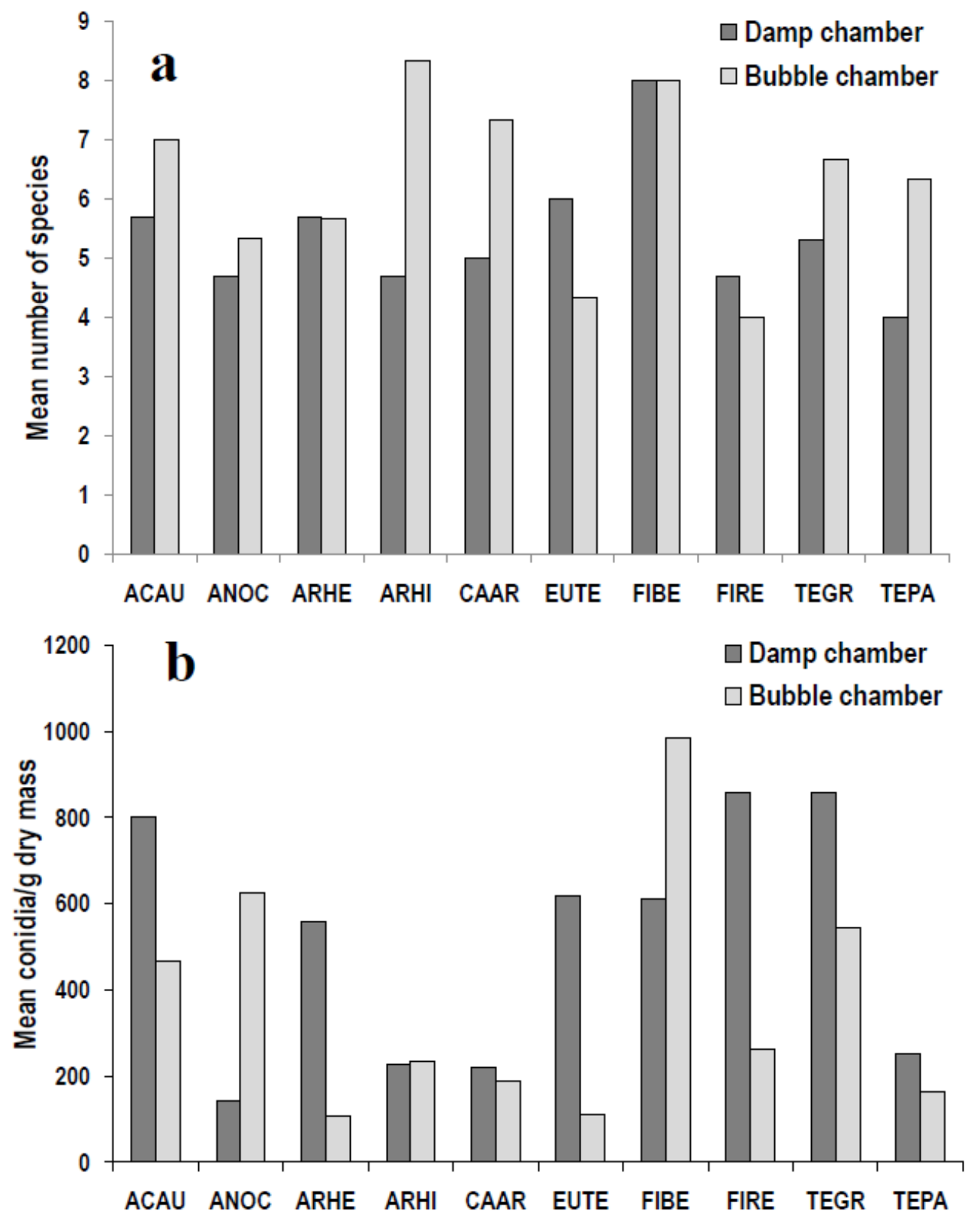

Fig. 5 - Mean number of species and mean conidia produced by the aquatic hyphomycetes in damp and bubble chamber incubations of 10 leaf litters $(n=3$, mean) (Tree species: ACAU, Acacia auriculiformis; ANOC, Anacardium occidentale; ARHE, Artocarpus heterophyllus; ARHI, Artocarpus hirsutus; CAAR, Careya arborea; EUTE, Eucalyptus tereticornis; FIBE, Ficus benghalensis; FIRE, Ficus religiosa; TEGR, Tectona grandis; TEPA, Terminalia paniculata). 

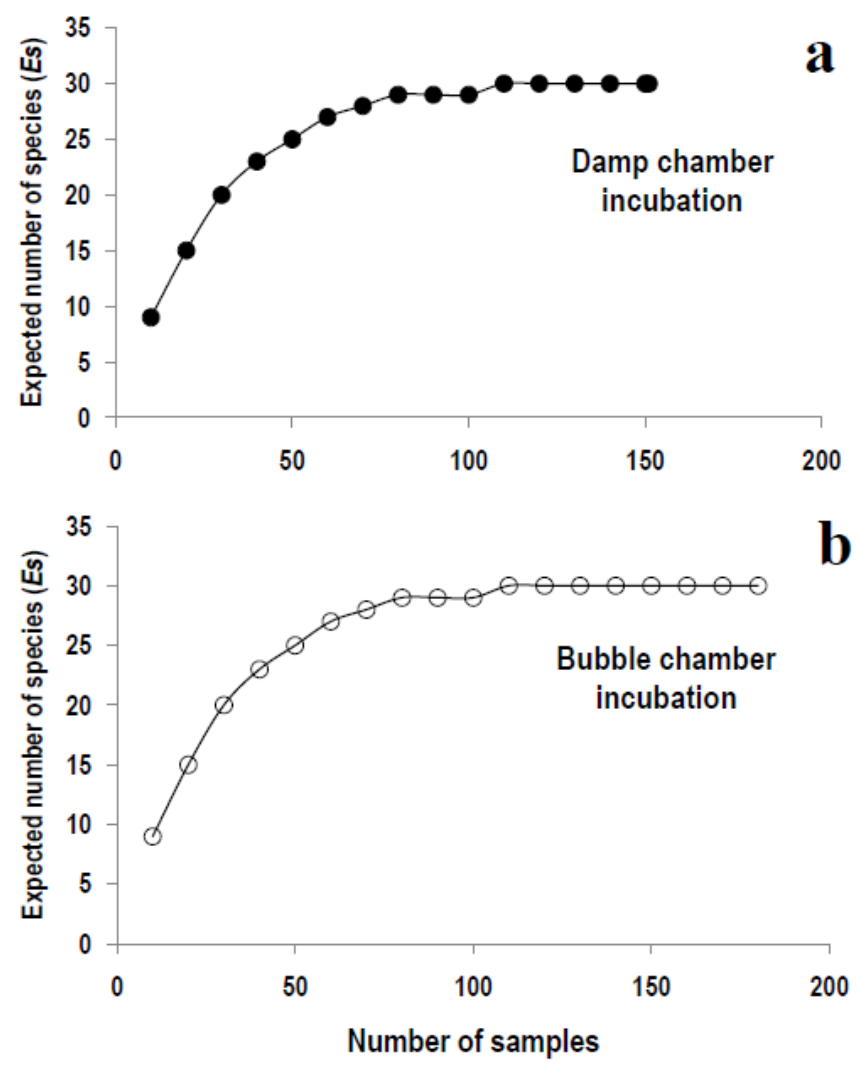

Fig. 6 - Rarefaction curves of expected number of species [ $\left.E_{(s 110)}\right]$ of aquatic hyphomycetes among 110 random samples by damp chamber and bubble chamber incubations.
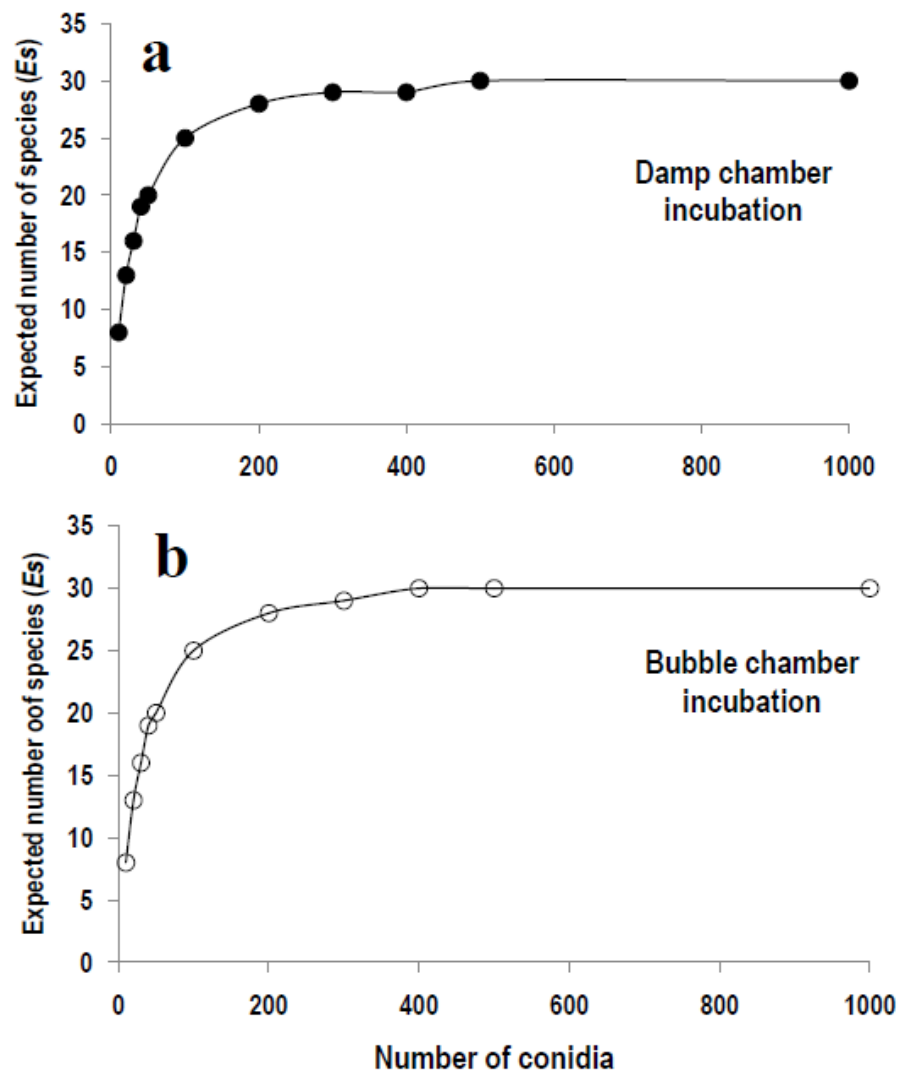

Fig. 7 - Rarefaction curves of expected number of species $\left[E_{(s 500)}\right]$ of aquatic hyphomycetes among 500 random conidia by damp chamber and bubble chamber incubations. 


\section{Discussion}

\section{Damp chamber incubation}

The damp chamber incubation is one of the common methods to assess the fungal colonization on plant materials. The conidia present on the surface of damp leaves were removed by rinsing in distilled water. Damp incubation method facilitates the constant supply of water sufficient for growth and sporulation of colonized hyphomycetes. Among the 11 exclusive species, four species were typical aquatic hyphomycetes (Anguillospora angulata, A. crassa, Flagellospora penicillioides and Tumularia aquatica), while the rest were aero-aquatic hyphomycetes (three Helicosporium spp., Speiropsis pedatospora, Triposermum camelopardus, Dwayaangam sp. and unknown triradiate conidia). Unlike bubble chamber incubation, the damp chamber incubation showed uniformity in the frequency of occurrence as well as their percent conidial contribution.

\section{Bubble chamber incubation}

The bubble chamber incubation is one of the common methods followed to induce sporulation of aquatic hyphomycetes on submerged leaf litter in streams. The fine jet of air bubbles leads to mechanical stimulation and supply oxygen for sporulation for the colonized fungi (Iqbal \& Webster 1973). Usually, 48 hours of aeration is sufficient to induce conidia of the colonized fungi on the substrate. Among the 10 exclusive species, many were typical aquatic hyphomycetes (Alatospora acuminata, Anguillospora longissima, Anguillospora sp., Campylospora chaetocladia, C. parvula, Ingoldiella hamata, Isthmotricladia gombakiensis, I. laeensis and Tricladium sp.), while the Tripospermum myrti and unknown sigmoid conidial fungus seem to be aero-aquatic hyphomycetes.

\section{Other studies}

Similar to the present study, many surveys were carried out to screen the aquatic and aeroaquatic hyphomycetes present in several tree species (canopy leaf litter, stemflow and throughfall) (Sridhar et al. 2006, Karamchand \& Sridhar 2008, 2009, Sudheep \& Sridhar 2010, Ghate \& Sridhar 2015a, 2016). As many aquatic and aero-aquatic hyphomycetes occur in the canopy, they will be transferred to the leaf litter beneath the canopy as the inocula. However, the occurrence of hyphomycetes as endophytes in the canopy substrates (e.g. live leaves, twigs and bark) cannot be ruled out.

Among the various leaf litters present in the streams, banyan leaf litter (Ficus benghalensis) served as an ideal substrate for the colonization of aquatic hyphomycetes (Sridhar \& Kaveriappa 1989). In the present study also, the leaf litter of $F$. benghalensis served as a superior substrate for fungi. In addition, leaf liter of $A$. auriculiformis and $T$. grandis were also worth considering as good substrates as they supported more species and high conidial output. Probably, the texture, nutrient composition of the above leaf litter and physicochemical conditions of scrub jungles prevailing in southwestern India seem to be ideal for the colonization, survival and perpetuation of aquatic hyphomycetes.

\section{Conidial output}

According to earlier reports, aquatic hyphomycetes under optimum conditions (e.g. substrate quality and physicochemical features) produce up to 8 million conidia per gram dry mass of leaf litter per day (Gessner 1997). In the present study, up to 1850 conidia were produced in two days per gram of dry mass from the preferred leaf litter of Ficus benghalensis. It corresponds to about $0.012 \%$ compared to the leaf litter which exists in the streams. This is obvious because the natural damp conditions underneath the canopy are not equivalent to stream habitats for aquatic hyphomycetes. However, the scrub jungles of the southwest of India provide almost continuous dampness for a long period during southwest monsoon (June-November). Interestingly, the aquatic hyphomycetes in naturally dried leaf litter present in the tree holes also produced conidia during the summer in the Western Ghats and west coast of India (602-2841 and 552-684 conidia/g dry mass, 
respectively) (Sridhar et al. 2006, Karamchand \& Sridhar 2008, Sudheep \& Sridhar 2010). Similarly, aquatic hyphomycetes were found in dried bracket leaves of the epiphytic fern (Drynaria quersifolia (L.) J. Sm.) during summer (Karamchand \& Sridhar 2009).

\section{Niche duality}

Niche duality of aquatic fungi is one of the interesting concepts in fungal ecology (Colwell and Rangel 2009, Sélosse et al. 2018). Although aquatic fungi mainly adapted to flowing waters, their occurrence or distribution outside their usual habitat (e.g. terrestrial damp litter and tree holes) is helpful to replenish their conidia or propagules to the streams having unidirectional flow (Sridhar et al. 2013, Chauvet et al. 2016). The route of transport from terrestrial to aquatic or vice versa will be interesting. It may happen through wind, insects, foam and input of live or dead aerial parts of riparian tree species colonized by endophytic/saprophytic hyphomycetes. The nearest stream to the investigation region of this study (Konaje stream), which showed richness ranging from 10-22 species by following any one the methods of assessment (Sridhar \& Kaveriappa 1984, 1989, Sridhar et al. 2013, Ghate \& Sridhar 2015b). In the present study, the richness ranged from 20-21 species in both methods of incubation. However, the species composition and the conidial output varied between the methods, probably due to the substrates and environmental factors. The role of aquatic hyphomycetes in terrestrial habitats in catering to the nutritional needs of terrestrial or semi-terrestrial fauna needs further study. The role of these fungi in carbon cycling in regions receiving heavy rains will be an interesting topic to investigate.

\section{Conclusions}

Based on the two methods of incubation, 31 species of aquatic fungi were recorded. Among them, 10 species were common to both incubation methods; 11 and 10 species were exclusive to damp and bubble chamber incubation methods, respectively. Hence, both methods of incubation will be necessary to get a better picture of colonized mycota in damp leaf litter. According to the present study, based on species richness and conidial output, leaf litter of Acacia auriculiformis, Ficus benghalensis and Tectona grandis are the ideal substrates for colonization of aquatic hyphomycetes. Among the 10 core-group hyphomycetes found in both methods, Flagellospora curvula, Lunulospora curvula and Triscelophorus konajensis were common. Hence, they deserve special attention and need to assess their role in damp leaf litter. Although the extent of aquatic fungi in terrestrial habitats is not up to the extent of flowing waters, the roles played by them in terrestrial habitats is one of the important issues in fungal ecology. Further studies are necessary to ascertain the presence of loose conidia on the leaf litter during the summer season, their viability and recolonization of leaf litter on the onset of monsoon.

\section{Acknowledgements}

The authors are thankful to the Department of Biosciences, Mangalore University for extending the facilities to carry out this study. The authors acknowledge the constructive effort of the referees and editors to improve the draft of this manuscript.

\section{References}

Bao D-F, Luo ZL, Liu JK, Bhat DJ et al. 2018 - Lignicolous freshwater fungi in China III: New species and record of Kirschsteiniothelia from northwestern Yunnan Province. Mycosphere 9, 755-768.

Chauvet E, Cornut J, Sridhar KR, Sélosse M-A, Bärlocher F. 2016 - Beyond the water column: Aquatic hyphomycetes outside their preferred habitats. Fungal Ecology 19, 112-127.

Colwell RK, Rangel TF. 2009 - Hutchinson's duality: The once and future niche. Proceedings of the National Academy of Science 106, 19651-19658.

Duarte S, Bärlocher F, Pascoal C, Cássio F. 2016 - Biogeography of aquatic hyphomycetes: Current knowledge and future perspectives. Fungal Ecology 19, 169-181. 
Friggens NL, Taylor JE, Koukol O. 2017 - Diversity and community composition of aquatic ascomycetes varies between freshwater, estuarine and marine habitats in western Scotland. Mycosphere 8, 1267-1287.

Gessner MO. 1997 - Fungal biomass, production and sporulation associated with particulate organic matter in streams. Limnetica 13, 33-44.

Ghate SD, Sridhar KR. 2015a - Rain-borne fungi in stemflow and throughfall of six tropical palm species. Czech Mycology 67, 45-58.

Ghate SD, Sridhar KR. 2015b - A new technique to monitor conidia of aquatic hyphomycetes in streams using latex-coated slides. Mycology 6, 161-167.

Ghate SD, Sridhar KR. 2016 - Aquatic hyphomycetes with leaves, leaf detritus and crown humus in palm canopies. Czech Mycology 68, 111-126.

Gulis V, Marvanová L, Descals E. 2005 - An illustrated key to the common temperate species of aquatic hyphomycetes. In: Graça MAS, Bärlocher F, Gessner MO (eds) Methods to Study Litter Decomposition: A Practical Guide. Springer, 153-168.

Huang S-K, Jeewon R, Hyde KD, Bhat JD et al. 2018a - Beta-tubulin and actin gene phylogeny supports Phaeoacremonium ovale as a new species from freshwater habitats in China. MycoKeys 41, 1-15.

Huang S-K, Jeewon R, Hyde KD, Bhat JD, Wen TC. 2018b - Novel taxa within Nectriaceae: Cosmosporella gen. nov. and Aquanectria sp. nov. from freshwater habitats in China. Crytogamie Mycologie 39, 169-192.

Hyde KD, Jeewon R. 2003 - Physiological studies and molecular diversity of freshwater lignicolous fungi. In: Tsui CKM, Hyde KD (eds) Freshwater Mycology. Fungal Diversity Research Series \# 10, Hong Kong University Press, 173-193

Ingold CT. 1975 - Guide to Aquatic and Water-Borne Hyphomycetes (Fungi Imperfecti) with Notes on their Biology. Scientific Publication \# 30. Ambleside, Cumbria, UK.

Iqbal SH, Webster J. 1973 - The trapping of aquatic hyphomycete spores by air bubbles. Transactions of the British Mycological Society 60, 37-48.

Karamchand KS, Sridhar KR. 2008 - Water-borne conidial fungi inhabiting tree holes of the west coast and Western Ghats of India. Czech Mycology 60, 63-74.

Karamchand KS, Sridhar KR. 2009 - Association of water-borne conidial fungi with epiphytic tree fern (Drynaria quercifolia). Acta Mycologica 44, 19-27.

Ludwig JA, Reynolds JF. 1988 - Statistical Ecology - A Primer on Methods and Computing. John Wiley and Sons, New York.

Luo Z, Hyde KD, Liu J, Maharachchikumbura SSN, Jeewon R et al. 2019 - Freshwater Sordariomycetes. Fungal Diversity 99, 451-660.

Luo, Z-L, Bhat DJ, Jeewon R, Boonmee S et al. 2017 - Molecular phylogeny and morphological characterization of asexual fungi (Tubeufiaceae) from freshwater habitats in Yunnan, China. Cryptogamie Mycologie 38, 1-28.

Magurran AE. 1988 - Ecological Diversity and its Measurement. Princeton University Press, New Jersey.

Marvanová L. 1997 - Freshwater hyphomycetes: A survey with remarks on tropical taxa. In: Janardhanan KK, Rajendran C, Natarajan K, Hawksworth DL (eds) Tropical Mycology. Science Publishers, New York, 169-226.

Nawawi A. 1985 - Aquatic hyphomycetes and other waterborne fungi from Malaysia. Malaysian Nature Journal 39, 75-134.

Pielou FD. 1975 - Ecological Diversity. Wiley InterScience, New York.

Raja HA, Shearer CA, Tsui CKM. 2018 - Freshwater fungi. In: Microbiology. John Wiley \& Sons Ltd., Chichester: 10.1002/9780470015902.a0027210.

Sélosse MS, Schneider-Maunoury L, Martos F. 2018 - Time to re-think fungal ecology? Fungal ecological niches are often prejudged. New Phytologist 207, 968-972. 
Santos-Flores CJ, Betancourt-Lopez C. 1997 - Aquatic and waterborne hyphomycetes (Deuteromycotina) in streams of Puerto Rico (including records from other Neotropical locations). Caribbean Journal of Science (Special Publication \#2), 1-116.

Shearer CA, Descals E, Kohlmeyer B, Kohlmeyer J et al. 2007 - Fungal biodiversity in aquatic habitats. Biodiversity and Conservation 16, 49-67.

Sridhar KR, Bärlocher F. 1993 - Aquatic hyphomycetes on leaf litter in and near a stream in Nova Scotia, Canada. Mycological Research 97, 1530-1535.

Sridhar KR, Karamchand KS, Bhat R. 2006 - Arboreal water-borne hyphomycetes with oak-leaf basket fern Drynaria quercifolia. Sydowia 58, 309-320.

Sridhar KR, Karamchand KS, Seena S. 2013 - Fungal assemblage and leaf litter decomposition in riparian tree holes and in a coastal stream of the south-west India. Mycology 4,118-124.

Sridhar KR, Kaveriappa KM. 1984 - Seasonal occurrence of water-borne fungi in Konaje stream (Mangalore), India. Hydrobiologia 119, 101-105.

Sridhar KR, Kaveriappa KM. 1987 - Occurrence and survival of aquatic hyphomycetes in terrestrial conditions. Transactions of the British Mycological Society 89, 606-609.

Sridhar KR, Kaveriappa KM. 1989 - Colonization of leaves by water-borne hyphomycetes in a tropical stream. Mycological Research 92, 392-396.

Sridhar KR. 2009 - Fungi in the tree canopy - An appraisal. In: Rai M, Bridge P (eds) Applied Mycology. CAB International, UK, 73-91.

Su X-j, Luo Z-L, Jeewon R, Bhat DJ et al. 2018 - Morphology and multigene phylogeny reveal a new genus and two new species of Torulaceae from freshwater habitats in northwestern Yunnan, China. Mycological Progress 17, 1-15.

Sudheep NM, Sridhar KR. 2010 - Water-borne hyphomycetes in tree canopies of Kaiga (Western Ghats), India. Acta Mycologica 45, 185-195.

Vijaykrishna D, Jeewon R, Hyde KD. 2005 - Fusoidispora aquatica: New freshwater ascomycetes from Hong Kong based on morphology and molecules. Sydowia 57, 267-280.

Vijaykrishna D, Jeewon R, Hyde KD. 2006 - Molecular taxonomy, origins and evolution of freshwater ascomycetes. Fungal Diversity 23, 367-406.

Zhang Y, Jeewon R, Fournier J, Hyde KD. 2008 - Multi-gene phylogeny and morphotaxonomy of Amniculicola lignicola: Novel freshwater fungus from France and its relationships to the Pleosporales. Fungal Biology 112, 1186-1194.

Zhao GZ, Liu XZ, Wu WP. 2007 - Helicosporous hyphomycetes from China. Fungal Diversity 26, 313-524. 